\title{
Effect of Mineral and Bio Potassium Fertilizer and Foliar Spray with Different Sources of Boron on Productivity and Quality of Strawberry for Exportation
}

\author{
Shafshak, Nadia S., L. A. Badr, M. H. M. Mohamed and A. S.M. Abd ELAziz \\ Department of Horticulture, Faculty of Agriculture, Moshtohor, Benha University. \\ Corresponding author: mustafa.muhammed@fagr.bu.edu.eg
}

\begin{abstract}
The field experiment was carried out during the two successive winter seasons 2017/2018 and 2018/2019 in private sector farm at Badr center, El-Behira Governorate, to investigate the effect of mineral and bio potassium fertilizer as well as the foliar spray with different sources of boron (chelated boron, boric acid and nano boron) on growth, chemical composition, fruit yield and quality of strawberry plants (Fragaria X ananassa Duch) cv. Sensation. This experiment included 16 treatments resulted from the combination between four potassium fertilizers treatments, $100 \%$ recommend dose of mineral potassium fertilizers $350 \mathrm{~kg}$ potassium sulphate (The control treatment), $120 \%$ recommend dose of mineral potassium fertilizers $420 \mathrm{~kg}$ potassium sulphate, $80 \%$ recommend dose of mineral potassium fertilizers $280 \mathrm{~kg}$ potassium sulphate+ potassin and $60 \%$ recommend dose of mineral potassium fertilizers $210 \mathrm{~kg}$ potassium sulphate+ potassin as well as four foliar spray treatments, chelated boron at $100 \mathrm{ppm}$, boric acid at $100 \mathrm{ppm}$, nano boron at $100 \mathrm{ppm}$ and the control treatment (spray with tap water). Obtained results showed that application of $80 \%$ recommend dose of mineral potassium fertilizers + potassin bio fertilizer $(280 \mathrm{~kg} / \mathrm{Fed}$. potassium sulphate+ potassin) then spray the plants six times starting after 30 days of transplanting and every 15 days intervals with Chelated boron at100ppm exhibited the highest values in all measured growth parameters, chemical composition of plant foliage, exportable yield as well as total produced yield with best fruit quality.
\end{abstract}

Key words: strawberry - potassium fertilizer - boron sources - yield - fruit quality.

\section{Introduction}

Strawberry (Fragaria X ananassa Duch.) is one of the most important vegetable crops grown in Egypt for fresh consumption, processing and exportation. The growth, production and quality of strawberry fruit are depending on the different agricultural treatments done during the growing season. Nowadays, in the term fertilization with macronutrients, many farmers use growth stimulants either as a soil addition or foliar spray to improve growth, productivity and yield quality of produced fruits.

Potassium is also an essential major nutrient for plant growth and development. Plants absorb more $\mathrm{K}$ than any other element, with the exception of $\mathrm{N}$ Treder $\boldsymbol{e t}$ al. (2014). Also, Potassium is particularly important in terms of berry quality providing a high sugar and acid content, and a good taste to the fruit Afroz et al. (2016). It is important for transpiration and regulates stomatal opening and closing, helping improve water use efficiency particularly in periods of moisture stress. Potassium is involved in a range of transport and accumulation processes within the plant, including the translocation of nitrates and activation of some enzymes. It can also help minimize the effects of stresses such as frost by increasing the osmotic potential and therefore lowering the freezing point of the cell solution Lisjak et al. (2008) and Schwarz et al. (2018).

Biofertilizers are microbial inoculants consisting of living cells of micro-organisms such as bacteria, algae and fungi either alone or in combination which may help in increasing vegetable crops productivity (Karlidag et al., 2010). Biofertilizers are easy to apply, low-cost in nature and eco-friendly. A judicious combination of organic manures, inorganic fertilizers and biofertilizers might be helpful in obtaining high strawberry productivity and good soil health for sustainability. can improve plant growth directly through the production of phytohormones as gibberellins, cytokinins and indole acetic acid which act as growth promoters and indirectly through nitrogen fixation and production of bio-control agents against soil-borne phytopathogens and consequently increase formation of metabolites which enhance the plant vegetative growth and increase the meristematic activity of tissues to induce good growth (Tripathi $\boldsymbol{e t}$ al.,2017). bio-fertilizer may induce growth promotion directly or indirectly. Directly influence include production of phytohormons, improving availability of nutrients, non-symbiotic nitrogen fixation and stimulation of disease resistance mechanisms which all together may promote the vegetative growth. Indirect effect arises and altering the root environment and ecology (Kumari et al.,2018 and Morais et al.,2019).

Boron (B) is one of the important micronutrients that has basic role in stabilizing certain constituents of cell walls structure and function and activity of plasma membrane, improvement of cell division, tissue differentiation. So, boron could be directly joined with cell growth (Goldbach et al., 1990). In addition, Rafeii and Pakkish (2014) revealed that application of boron increased net photosynthetic rate that could 
be attributed to the increase in chlorophylls content of leaves. Also, boron has been involved in metabolism of nucleic acid, carbohydrate, protein, auxin and phenol. Moreover, boron has been role in sugar translocation, nucleic acids synthesis and pollen tube growth. Also, Boron plays a key role in higher plants by facilitating the short - and long- distance transport of sugar via the formation of borate- sugar complexes (Bragg et al. 2008, Esringu et al. 2011, Ozkutlu et al. (2017 and Rosa et al. 2018).

Therefore, the present study was carried out to investigate the effect of mineral and bio potassium fertilizer levels as well as the foliar spray with different sources of boron (chelated boron, boric acid and nano boron) on strawberry growth, productivity and fruit quality .

\section{Materials and methods}

The field experiment was carried out during the two successive winter seasons 2017/2018 and 2018/2019 in private sector farm at Badr center, ElBehira Governorate, to investigate the effect of mineral and bio potassium fertilizer as well as the foliar spray with different sours of boron (chelated boron, boric acid and nano boron) on growth, chemical composition, fruit yield and quality of strawberry plants (Fragaria $X$ ananassa Duch) cv. Sensation. Transplants were dipped in Rhizolex solution at rate of $3.0 \mathrm{~g} /$ liter for 20 minutes as recommended by Ministry of Agriculture for pathogen disinfection before transplanting. The soil of the experimental field was sandy in texture with $\mathrm{pH}$ 7.3. Soil mechanical and chemical analyses are shown in Table 1.

The area of the experimental plot was $11.90 \mathrm{~m}^{2}$ included one bed of seven meter long and 1.70 meters in width. Each bed included four rows and the transplanting was done at $25 \mathrm{~cm}$ apart between transplants in the same row. Transplanting was done on $15^{\text {th }}$ of September both seasons of study. Sprinkler and drip irrigation was used in the first month after transplanting, after that the beds were covered with 40 micron black plastic mulch. Then the drip irrigation was used only after mulching until the end of the growing season. .

Table a. Soil mechanical and chemical analyses of the used soil

\begin{tabular}{|c|c|c|c|c|c|}
\hline \multirow{2}{*}{\multicolumn{2}{|c|}{ Physical analysis }} & \multicolumn{4}{|c|}{ Chemical analysis } \\
\hline & & \multicolumn{2}{|c|}{ Cations meq/l } & \multicolumn{2}{|c|}{ Anions meq/l } \\
\hline Coarse sand & $18.3 \%$ & $\mathbf{C a}^{++}$ & 8.9 & $\mathrm{CO3}^{--}$ & Zero \\
\hline Fine sand & $36.8 \%$ & $\mathbf{M g}^{++}$ & 3.15 & $\mathrm{HCO3}^{-}$ & 4.5 \\
\hline Silt & $27.5 \%$ & $\mathbf{N a}^{+}$ & 4.20 & $\mathrm{Cl}^{-}$ & 6.35 \\
\hline Clay & $18.4 \%$ & $\mathbf{K}^{+}$ & 1.18 & SO4-- & 8.10 \\
\hline \multicolumn{6}{|c|}{ Texture class sandy } \\
\hline Soil pH & 7.3 & \multirow{3}{*}{\multicolumn{2}{|c|}{$\begin{array}{l}\text { Available } \mathbf{N} \\
\text { Available } \mathbf{P} \\
\text { Available } \mathbf{K}\end{array}$}} & \multicolumn{2}{|l|}{$23.9 \mathrm{mg} / \mathrm{kg}$} \\
\hline E.C, $\mathrm{dS} / \mathrm{m}$ & 1.87 & & & \multicolumn{2}{|l|}{$12.6 \mathrm{mg} / \mathrm{kg}$} \\
\hline Organic matter & $2.6 \%$ & & & \multicolumn{2}{|l|}{$183 \mathrm{mg} / \mathrm{kg}$} \\
\hline
\end{tabular}

This experiment included 16 treatments resulted from the combination between four potassium fertilizers treatments and four foliar spray treatments as follow a. Potassium fertilizers treatments

1- $100 \%$ recommend dose of mineral potassium fertilizers $350 \mathrm{~kg}$ potassium sulphate (The control treatment).

2- $120 \%$ recommend dose of mineral potassium fertilizers $420 \mathrm{~kg}$ potassium sulphate.

3 - $\quad 80 \%$ recommend dose of mineral potassium fertilizers $280 \mathrm{~kg}$ potassium sulphate+ potassin.

4- $60 \%$ recommend dose of mineral potassium fertilizers $210 \mathrm{~kg}$ potassium sulphate+ potassin.

b. Foliar Spray treatments

1- Chelated boron at 100ppm.

2- Boric acid at 100ppm.

3- Nano boron at 100ppm.

4- The control treatment (spray with tap water).

Potassin contained efficient strains of silicate dissolving bacteria (SDB) (Bacillus circulans) which were produced by the department of Microbiology, Agric. Res. Center, Giza was applied at the rate of 20 1/fed through drip irrigation two times, the first one starting after two weeks from transplanting and the second after two weeks in the two seasons.

The mineral potassium fertilizer treatments were added through the irrigation water (fertigation) starting two weeks after transplanting and every week interval. The spray treatments were started after 30 days from transplanting and every 15 day intervals through the growing season. A split plot design with three replicates was used in this experiment where the potassium fertilizers treatments were distributed in the main plots and the spray treatments were located randomly in the sub plots. The other agricultural practices concerning cultivation, fertilization, irrigation and pest- and disease control were conducted as commonly followed in the district

\section{Data recorded}

a. Vegetative growth characteristics

Five plants were taken from each experimental plot as a representative sample after130 days from transplanting and plant height, number of crowns/plant, number of leaves/plant, fresh weight as well as dry weight per plant were recorded. 
b. Chemical composition of plant foliage: Total nitrogen, phosphorus, potassium and carbohydrates content were determined according to Pregl (1945), John (1970), Brown and Lilleland (1946) and Rowell (1995), respectively

c. Fruit yield and its components

Early fruit yield: It was determined as weight of all harvested fruits at the ripe stage during November, December and January

Exportable yield: It was calculated as weight of harvested fruits at the ripe stage during November, December and January after discarding the misshaped fruits

Total fruit yield: It was calculated as weight of all fruits harvest allover the growing season

Fruit yield per plant:It was calculated from fruit yield/plot divided by number of plants/plot

d. Chemical quality

Total soluble solids (T.S.S.): A random sample of 10 fruits from each experimental plot at full ripe stage was taken to determine the percentage of soluble solids content by using hand refractometer

Total titratable acidity (T.T.A), ascorbic acid "Vitamin C" and anthocyanin content were determined according to the methods described in $\mathbf{A}$. O. A.C. (1990).

Total sugars: Reducing and total sugars were determined in dry samples of ripe fruits for each experimental plot colormetrically by the method described by Nelson (1974)

Statistical analysis

All collected data were subjected to statistical analysis (split plot design) according to Sndecor and Cochran (1991) where the least significant difference was considered whenever possible.

\section{Result and Discussion}

\section{Vegetative growth characteristics.}

Data presented in Table 1 show that application of different levels of potassium fertilizer, i.e., $120 \%$, $100 \%, 80 \%, 60 \%$ of the potassium recommended dose (350 kg/Fed. potassium sulphate) significantly affected all the studied growth traits, i.e., plant height, number of leaves, total fresh and dry weight per plant during both seasons of study. On contrary, such differences did not reach the level of significance in case of number of crowns per plant in both seasons. In this respect, decreasing the rate of application by 20 $\%$ of recommended dose and adding potassin bio fertilizer $(280 \mathrm{~kg} / \mathrm{Fed}$. potassium sulphate+ potassin) followed by $100 \%$ of recommended dose (350 $\mathrm{kg} / \mathrm{Fed}$. potassium sulphate) and $120 \%$ of recommended dose (420 kg/Fed. potassium sulphate) significantly reflected the highest values in all studied growth traits compared with decreasing the amounts by $40 \%$ of decided amounts. In addition, no significant differences were found between the application of fertilizers at $120 \%, 100 \%$ or $80 \%$ of the recommended dose in most vegetative growth traits during both seasons of growth but sometimes $80 \%$ of the recommended dose with added and potassin bio fertilizer excided on $100 \%$ or $120 \%$ of the recommended dose in most of studied traits. In this connection, such increments in all studied growth parameters as a result of decreasing the amounts of mineral fertilizers to $80 \%$ of the recommended dose with added potassin bio fertilizer may be attributed to the main role of macro- martinets $(\mathrm{N}, \mathrm{P}$ and $\mathrm{K})$ on formation of protoplasmic material, cells division and elongations bio- chemicals interaction which affect the rate of plant growth. In this regard, Lisjak et al. (2008), Treder et al. (2014), Afroz et al. (2016), Kumari et al.(2018), Schwarz et al. (2018) and Morais et al.(2019) reported similar results.

Such data in Table 1 reveal that spraying strawberry plants with different sources of boron, i.e., Chelated boron, Boric acid and Nano boron at 100ppm after 30 days from transplanting and every 15 day intervals through the growing season significantly increased plant vegetative growth expressed as plant height, number of leaves and crowns per plant as well as fresh and dry weight per plant compared with the control treatment. In this regard, spraying the plants with Chelated boron followed by boric acid at rate at $100 \mathrm{ppm}$ gave the significant highest values of plant height, number of leaves and crowns per plant as well as fresh and dry weight per plant in both seasons. Obtained results are similar during the two seasons of growth. Bragg et al. (2008), Esringu et al. (2011), Rafeii and Pakkish (2014), Ozkutlu et al. (2017) and Rosa et al. (2018) reported similar results .

As for the Effect of the interaction, data recorded in Table 1 show clearly that application of $80 \%$ RDK adding potassin bio fertilizer $(280 \mathrm{~kg} / \mathrm{Fed}$. potassium sulphate+ potassin) then spray the plants six times starting after 30 days of transplanting and every 15 days intervals with Chelated boron at.100ppm exhibited the highest values in all measured growth parameters during both seasons of study. However, significant differences were noticed in most of plant measurements among the other studied interaction treatments under the same level of fertilization.

\section{Chemical constituents of plant foliage.}

With regard to the effect of potassium levels, data recorded in Table (2) show clearly that total nitrogen, phosphorus, potassium, boron and total carbohydrates were significantly different as a result of the tested amounts of mineral fertilizer added with bio fertilizer during both seasons of study. In this connection, application of potassium fertilizers at $80 \%$ added with bio fertilizer $(280 \mathrm{~kg} / \mathrm{Fed}$. potassiumsulphate + potassin) followed by $120 \%$ of the recommended dose without added bio fertilizer $(420 \mathrm{~kg} / \mathrm{Fed}$. potassium sulphate) reflected the highest values in all assayed chemical constituents compared with using mineral fertilizers at the recommended dose or at $60 \%$ of it during the two seasons of study. Such increments in 
$\mathrm{N}, \mathrm{P}$ and $\mathrm{K}$ content as well as $\mathrm{B}$ and total carbohydrates as a result of increments in increasing the amounts of added mineral fertilizers may be due to the increase of such nutrient in roots and consequently increases its uptake and accumulation of such macronutrients Also the increase in total carbohydrate content might attributed to the main role of used macro- nutrients (NPK) as constituents of photosynthetic pigment molecules and assimilation rate for precursors of carbohydrates in leaves. This results are in agreement with those reported by Lisjak et al. (2008), Treder et al. (2014), Afroz et al. (2016), Kumari et al.(2018), Schwarz et al. (2018) and Morais et al.(2019) .

Data presented in Table 3 indicate that foliar spraying strawberry plants with Chelated boron, Boric acid and/or Nano boron at 100ppm started after 30 days from transplanting and every 15 day intervals through the growing season significantly increased total nitrogen phosphorus, potassium, boron and total carbohydrates content in plant foliage compared to the control treatment. In addition, the highest values in all determined chemical constituents were recorded in case of using Chelated boron followed by Boric acid at $100 \mathrm{ppm}$ compared with control which recorded the lowest values. Such results are true during both seasons of study. In this respect, the increments in macro nutrient and carbohydrates as a result of using Chelated boron may be attributed to the role of such compounds in increasing the availability of macronutrients to plant absorption and or increasing the passive force in plants required for nutrient elements absorption and consequently increased its content in plant foliage, furthermore, such tested organic compound play a positive role on carbohydrates assimilation through the photosynthetic process and consequently increased plant foliage. In this regard, Bragg et al. (2008), Esringu et al. (2011), Rafeii and Pakkish (2014), Ozkutlu et al. (2017) and Rosa et al. (2018) reported similar results .

As for the effect of the interaction treatments between different levels of potassium fertilizer added with bio fertilizer and spray with different sources of boron on total nitrogen, phosphorus and potassium as well as boron and total carbohydrates content of plant foliage during the two seasons of growth, data in Table 4 clearly show that, application of mineral fertilizers $(\mathrm{K})$ at rate of $80 \%$ of recommended dose with bio fertilizer $(280 \mathrm{~kg} /$ fed. potassium sulphate+ potassin) and spraying the plants with Chelated boron reflected the highest values in all assayed chemical constituents followed by $120 \% \mathrm{~K}$ as soil addition + chelate boron as foliar application during the two seasons of growth.

\section{Fruit yield and its components}

Data in Table 3 show that total produced yield and its components expressed as exportable, marketable and total fruit yield per plant and feddan were significantly affected by the application of different levels of potassium fertilizer at the recommended dose or at
$120 \%$ and $80 \%$ of it during both seasons of study. In this respect, application mineral potassium fertilizer at $80 \%$ of recommended dose with added bio fertilizer $(280 \mathrm{~kg} / \mathrm{Fed}$. potassium sulphate+ potassin) exhibited the highest values for total produced yield and its components followed by treatment fertilized by $120 \%$ and $100 \%$ of the recommended dose (420 and/or 350 $\mathrm{kg} /$ fed. potassium sulphate) in descending order, However, no significant differences were noticed between treatments in which the plants fertilized with mineral potassium fertilizers at $100 \%$ and $120 \%$ of the recommended dose during the two seasons of study. Meanwhile, non significant differences were detected between all levels of potassium used in this study for unmarketable fruit yield per feddan during the two seasons of study. In this regard, the higher total produced yield and its components in case of using the $80 \%$ of recommended dose with added bio fertilizer (280 $\mathrm{kg}$ potassium sulphate+ potassin) were connected with the increase in vegetative growth rate Tables 3 and 4 and fruit physical parameters (Table 6) which in turn affect the total fruit yield. This results are in agreement with those reported by Lisjak et al. (2008), Treder et al. (2014), Afroz et al. (2016), Kumari et al.(2018), Schwarz et al. (2018) and Morais et al.(2019) .

Concerning the effect of foliar spray with different sources of boron i.e. Chelated boron, Boric acid and Nano boron at 100ppm on total produced fruit yield and its components, the same data in Table 5 reveal that spraying the plants every 15 days intervals and started after 30 days from transplanting during the growing seasons by Chelated boron and/or Boric acid as a source of amino acid at rate of 100 ppm exhibited the highest values in all determined yield parameters compared with other studied foliar spray treatments during the two season. Moreover no significant difference were recorded in case of the unmarketable fruit yield among all tested spray treatments and the control one, such increments in total produced yield and its components were connected with the increase in vegetative growth Tables 1 and 2 which in turn affect the produceability of plants. Bragg et al. (2008), Esringu et al. (2011), Rafeii and Pakkish (2014), Ozkutlu et al. (2017) and Rosa et al. (2018) reported similar results .

With regard to the effect of the interaction treatments between potassium fertilizer levels and foliar spray with different sources of boron treatments on total fruits yield and its components, data in Table 6 reveal that using the rate $80 \%$ of the potassium recommended dose added with bio fertilizer and foliar spaying the plants with the Chelated boron or Boric acid (100ppm) reflected the highest values for total fruits yield and its components traits expressed as exportable, marketable and total fruit yield per feddan during the two seasons of study. 
Table 1. Effect of potassium levels as soil addition and boron sources as foliar spray and their interaction on vegetative growth characteristics of strawberry plant during 2017 and 2018 seasons.

\begin{tabular}{|c|c|c|c|c|c|c|c|c|c|c|c|}
\hline \multicolumn{2}{|l|}{ Treatments } & \multicolumn{5}{|c|}{$2017 / 2018$} & \multicolumn{5}{|c|}{$2018 / 2019$} \\
\hline Potassium fertilizers & Foliar spray & $\begin{array}{c}\text { Plant } \\
\text { height } \\
(\mathrm{cm})\end{array}$ & $\begin{array}{c}\text { No. of } \\
\text { Crowns/plant }\end{array}$ & $\begin{array}{l}\text { No. of } \\
\text { leaves } \\
\text { /plant }\end{array}$ & $\begin{array}{c}\text { Total } \\
\text { fresh } \\
\text { weight } \\
\text { (g/plant) }\end{array}$ & $\begin{array}{c}\text { Total } \\
\text { dry } \\
\text { weight } \\
\text { (g/plant) }\end{array}$ & $\begin{array}{c}\text { Plant } \\
\text { height } \\
(\mathbf{c m})\end{array}$ & $\begin{array}{c}\text { No. of } \\
\text { Crowns/plant }\end{array}$ & $\begin{array}{l}\text { No. of } \\
\text { leaves } \\
\text { /plant }\end{array}$ & $\begin{array}{c}\text { Total } \\
\text { fresh } \\
\text { weight } \\
\text { (g/plant) }\end{array}$ & $\begin{array}{c}\text { Total } \\
\text { dry } \\
\text { weight } \\
\text { (g/plant) }\end{array}$ \\
\hline $120 \%$ RDK & & 18.8 & 2.4 & 17.8 & 57.2 & 13.2 & 20.5 & 2.3 & 19.3 & 57.4 & 15.3 \\
\hline $100 \%$ RDK & & 20.8 & 2.3 & 20.5 & 56.0 & 13.8 & 20.9 & 2.5 & 20.8 & 56.8 & 13.3 \\
\hline 80\% RDK+potassin & & 21.8 & 2.4 & 22.4 & 56.6 & 13.8 & 21.6 & 2.3 & 21.3 & 59.5 & 15.3 \\
\hline $60 \%$ RDK+potassin & & $\mathbf{1 7 . 6}$ & 2.0 & 18.9 & 48.7 & 11.2 & $\mathbf{1 7 . 8}$ & 2.0 & 20.5 & 50.3 & 10.8 \\
\hline LSD at $5 \%$ & & 1.3 & NS & 1.7 & 4.3 & 1.9 & 1.9 & NS & 1.9 & 4.5 & 1.7 \\
\hline & $\begin{array}{l}\text { Chelated B at } \\
\text { 100ppm }\end{array}$ & 20.7 & 2.6 & 23.1 & 57.7 & 14.3 & 21.6 & 2.9 & 24.0 & 60.5 & 15.9 \\
\hline & $\begin{array}{l}\text { Boric acid at } \\
100 p p m\end{array}$ & 20.3 & 2.5 & 21.0 & 58.2 & 14.1 & 20.5 & 2.3 & 20.8 & 58.6 & 14.1 \\
\hline & $\begin{array}{l}\text { NanoBoron at } \\
\text { 100ppm }\end{array}$ & 19.3 & 2.3 & 19.3 & 54.1 & 12.6 & 19.8 & 2.2 & 19.6 & 55.3 & 13.3 \\
\hline & Control & 18.5 & 1.8 & 16.3 & 48.5 & 11.0 & 18.8 & 1.7 & 17.4 & 49.6 & 11.3 \\
\hline LSD at $5 \%$ & & 1.2 & 0.6 & 2.7 & 7.2 & 1.5 & 1.2 & 0.5 & 2.2 & 4.9 & 1.7 \\
\hline \multirow{5}{*}{$120 \%$ RDK } & Chelated B at 100ppm & 19.7 & 2.7 & 21.3 & 60.9 & 14.1 & 21.3 & 3.0 & 22.0 & 63.8 & 19.0 \\
\hline & Boric acid at 100ppm & 18.7 & 2.7 & 17.3 & 58.6 & 14.4 & 20.7 & 2.0 & 20.7 & 59.6 & 14.9 \\
\hline & NanoBoron at 100ppm & 18.3 & 2.3 & 16.3 & 58.4 & 14.0 & 21.0 & 2.3 & 18.3 & $\mathbf{5 7 . 1}$ & 14.2 \\
\hline & Control & 18.3 & 2.0 & 16.3 & 51.0 & 10.3 & 19.0 & 1.7 & 16.3 & 49.0 & 13.2 \\
\hline & Chelated B at 100ppm & 21.7 & 2.7 & 24.3 & 63.7 & 15.1 & 22.7 & 3.3 & 23.3 & 62.0 & 14.7 \\
\hline \multirow{4}{*}{$120 \%$ RDK } & Boric acid at 100ppm & 22.0 & 2.3 & 20.7 & 58.6 & 14.6 & 20.3 & 2.3 & 21.0 & 59.6 & 14.9 \\
\hline & NanoBoron at 100ppm & 20.3 & 2.3 & 19.7 & 51.6 & 12.9 & 21.0 & 2.3 & 20.3 & 57.1 & 14.0 \\
\hline & Control & 19.0 & 2.0 & $\mathbf{1 7 . 3}$ & 50.0 & 12.6 & 19.7 & 2.0 & 18.3 & 48.5 & 9.5 \\
\hline & Chelated B at 100ppm & 23.0 & 3.0 & 26.7 & 56.3 & 15.5 & 23.7 & 3.3 & 25.3 & 63.9 & $\mathbf{1 7 . 5}$ \\
\hline \multirow{4}{*}{$\begin{array}{c}80 \% \\
\text { RDK+potassin }\end{array}$} & Boric acid at 100ppm & 22.3 & 2.7 & 25.3 & 65.0 & 15.2 & 22.7 & 2.7 & 21.3 & 63.9 & 15.9 \\
\hline & NanoBoron at $100 \mathrm{ppm}$ & 21.7 & 2.3 & 21.3 & 56.3 & 13.2 & 20.3 & 2.0 & 20.3 & 58.9 & 15.8 \\
\hline & Control & 20.0 & 1.7 & 16.3 & 49.0 & 11.4 & 19.7 & 1.3 & 18.0 & 51.0 & 12.1 \\
\hline & Chelated B at 100ppm & 18.3 & 2.0 & 20.0 & 50.0 & 12.5 & 18.7 & 2.0 & 25.3 & 52.2 & 12.5 \\
\hline $60 \%$ & Boric acid at 100ppm & 18.3 & 2.3 & 20.7 & 50.8 & 12.2 & 18.3 & 2.3 & 20.3 & 51.2 & 10.8 \\
\hline \multirow[t]{2}{*}{ RDK+potassin } & NanoBoron at $100 \mathrm{ppm}$ & 17.0 & 2.0 & 20.0 & 50.0 & 10.3 & 17.0 & 2.0 & 19.3 & 47.9 & 9.4 \\
\hline & Control & 16.7 & 1.7 & 15.0 & 44.0 & 9.8 & 17.0 & 1.7 & 17.0 & $\mathbf{5 0 . 0}$ & 10.3 \\
\hline LSD at $5 \%$ & & 0.3 & NS & 5.2 & 14.3 & 2.9 & 0.2 & 1.1 & 4.3 & 9.3 & 3.2 \\
\hline
\end{tabular}


Table 2. Effect of potassium levels as soil addition and boron sources as foliar spray treatments as well as their interaction on chemical constituents of plant foliage during 2017 and 2018 seasons.

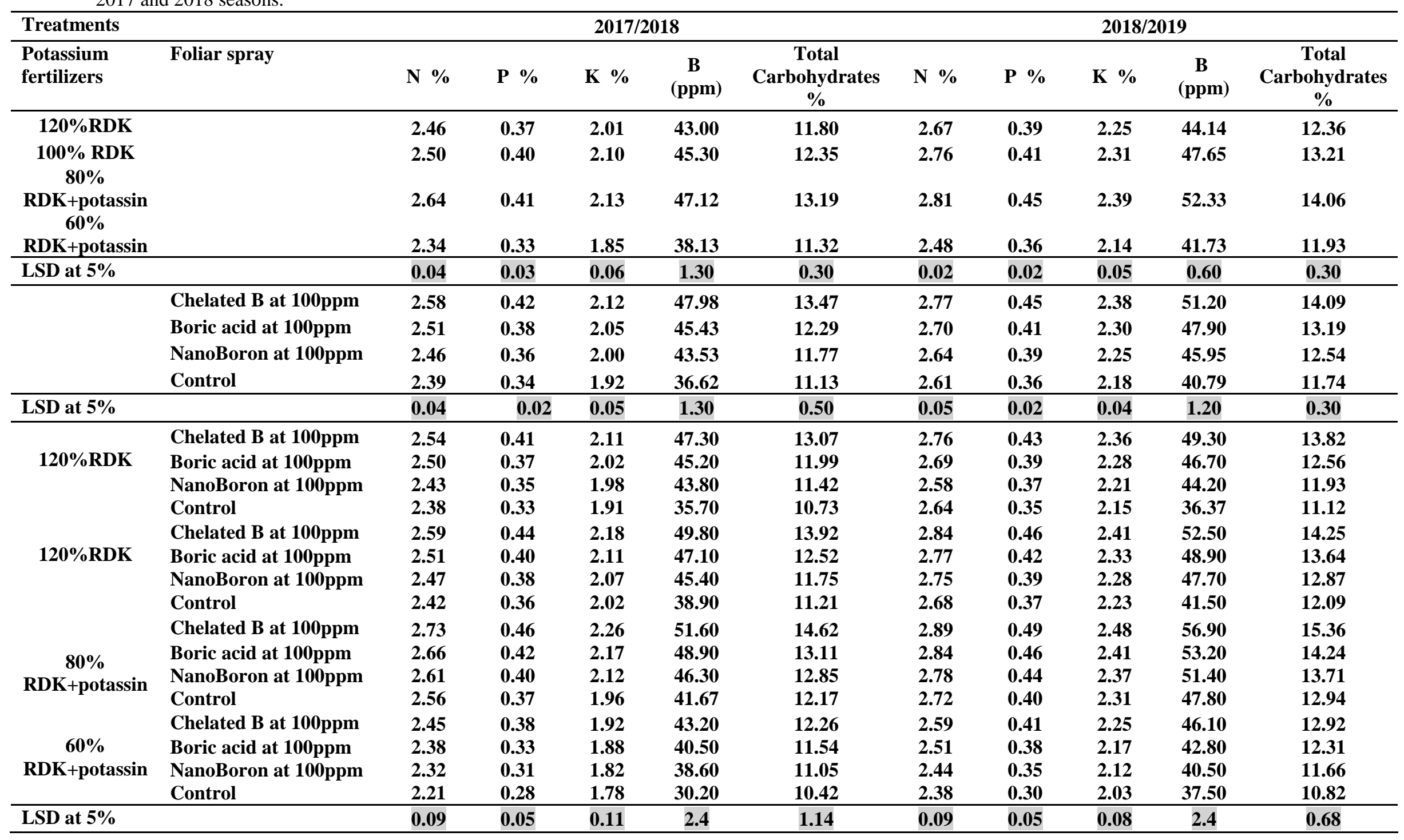


Table 3. Effect of potassium levels as soil addition and boron sources as foliar spray treatments as well as their interaction onfruit yield and its components of strawberry during 2017 and 2018 seasons.

\begin{tabular}{|c|c|c|c|c|c|c|c|c|c|}
\hline \multirow{2}{*}{$\begin{array}{l}\text { Treatments } \\
\text { Potassium fertilizers }\end{array}$} & \multirow[b]{2}{*}{ Foliar spray } & \multicolumn{4}{|c|}{$2017 / 2018$} & \multicolumn{4}{|l|}{$2018 / 2019$} \\
\hline & & $\begin{array}{c}\text { Exportable } \\
\text { yield } \\
(\text { ton/fed) }\end{array}$ & $\begin{array}{c}\text { Marketable } \\
\text { yield } \\
\text { (ton/fed) }\end{array}$ & $\begin{array}{c}\text { Total yield } \\
\text { (g) /plant }\end{array}$ & $\begin{array}{c}\text { Total yield } \\
\text { (ton /fed) }\end{array}$ & $\begin{array}{c}\text { Exportable } \\
\text { yield } \\
\text { (ton/fed) }\end{array}$ & $\begin{array}{c}\text { Marketable } \\
\text { yield } \\
\text { (ton/fed) }\end{array}$ & $\begin{array}{c}\text { Total yield } \\
\text { (g)/plant }\end{array}$ & $\begin{array}{c}\text { Total yield } \\
\text { (ton /fed) }\end{array}$ \\
\hline $120 \%$ RDK & & 7.217 & 14.450 & 458 & 22.125 & 7.478 & $\mathbf{1 3 . 8 9 7}$ & 525 & 21.900 \\
\hline $100 \%$ RDK & & 6.698 & 13.870 & 524 & 21.092 & 7.348 & 13.548 & 496 & 21.392 \\
\hline 80\% RDK+potassin & & 8.073 & 17.140 & 438 & 25.067 & 7.810 & 16.597 & 534 & 24.942 \\
\hline $60 \%$ RDK+potassin & & 4.520 & 10.073 & 482 & 15.075 & 4.994 & 9.945 & 536 & 15.475 \\
\hline \multirow[t]{5}{*}{ LSD at 5\% } & & 0.69 & 2.765 & NS & 1.849 & 0.64 & 0.858 & NS & 0.582 \\
\hline & Chelated B at 100ppm & 7.450 & 14.501 & 500 & 22.450 & 7.419 & 14.681 & 533 & 22.633 \\
\hline & Boric acid at 100ppm & 6.997 & 14.229 & 441 & 21.667 & 7.281 & 14.127 & 493 & 21.900 \\
\hline & NanoBoron at 100ppm & 6.429 & 14.414 & 482 & 21.325 & 7.023 & 13.610 & 517 & 21.150 \\
\hline & Control & 5.633 & 12.389 & 479 & 17.917 & 5.907 & 11.570 & 548 & 18.025 \\
\hline \multicolumn{2}{|l|}{ LSD at $5 \%$} & 0.609 & 1.482 & NS & 1.410 & 0.540 & 1.443 & NS & 1.197 \\
\hline \multirow{4}{*}{$120 \%$ RDK } & Chelated B at 100ppm & 7.999 & 15.867 & 433 & 24.300 & 8.281 & 15.169 & 550 & 24.000 \\
\hline & Boric acid at 100ppm & 7.397 & 14.369 & 433 & 22.200 & 8.030 & 14.287 & 483 & 22.800 \\
\hline & NanoBoron at $100 \mathrm{ppm}$ & 6.973 & 14.544 & 483 & 22.000 & 7.302 & 13.681 & 517 & 21.500 \\
\hline & Control & 6.498 & 13.019 & 483 & 20.000 & 6.300 & 12.450 & 550 & 19.300 \\
\hline \multirow{6}{*}{$120 \%$ RDK } & Chelated B at 100ppm & 7.797 & 13.586 & 617 & 22.000 & 7.599 & 14.501 & 567 & 22.667 \\
\hline & Boric acid at 100ppm & 6.997 & 14.390 & 513 & 21.900 & 7.496 & 14.504 & 500 & 22.500 \\
\hline & NanoBoron at 100ppm & 5.949 & 15.384 & 467 & 21.800 & 7.599 & 13.284 & 417 & 21.300 \\
\hline & Control & 6.048 & 12.118 & 500 & 18.667 & 6.696 & 11.904 & 500 & 19.100 \\
\hline & Chelated B at 100ppm & 8.899 & 18.168 & 433 & 27.500 & 8.498 & $\mathbf{1 7 . 7 0 2}$ & 467 & 26.667 \\
\hline & Boric acid at 100ppm & 8.796 & 18.054 & 417 & 27.267 & 7.999 & 18.298 & 503 & 26.800 \\
\hline \multirow{3}{*}{$80 \%$ RDK+potassin } & NanoBoron at 100ppm & 8.297 & 16.737 & 467 & 25.500 & 7.845 & 18.388 & 567 & 26.800 \\
\hline & Control & 6.300 & 15.602 & 433 & 20.000 & 6.898 & 12.002 & 600 & 19.500 \\
\hline & Chelated B at 100ppm & 5.103 & 10.381 & 517 & 16.000 & 5.297 & 11.353 & 550 & 17.200 \\
\hline \multirow{3}{*}{$60 \%$ RDK+potassin } & Boric acid at 100ppm & 4.798 & 10.102 & 400 & 15.300 & 5.598 & 9.418 & 483 & 15.500 \\
\hline & NanoBoron at $100 p p m$ & 4.497 & 10.993 & 510 & 16.000 & 5.347 & 9.086 & 567 & 15.000 \\
\hline & Control & 3.684 & 8.816 & 500 & 13.000 & 3.734 & 9.923 & 543 & 14.200 \\
\hline LSD at $5 \%$ & & 1.20 & 2.31 & NS & 14.3 & 1.10 & 1.34 & NS & 2.61 \\
\hline
\end{tabular}


Table 4. Effect of potassium levels as soil addition and boron sources as foliar spray treatments as well as their interaction onchemical fruit quality of strawberry during 2017 and 2018 seasons.

\begin{tabular}{|c|c|c|c|c|c|c|c|c|c|c|c|}
\hline \multirow{2}{*}{$\begin{array}{l}\text { Treatments } \\
\text { Potassium fertilizers }\end{array}$} & \multirow[b]{2}{*}{ Foliar spray } & \multicolumn{5}{|c|}{$2017 / 2018$} & \multicolumn{5}{|c|}{$2018 / 2019$} \\
\hline & & TSS \% & $\begin{array}{c}\text { Total } \\
\text { Acidity \% }\end{array}$ & $\begin{array}{c}\text { Vit. C } \\
\text { (mg/100g } \\
\text { f.w) }\end{array}$ & $\begin{array}{c}\text { Total } \\
\text { sugars\% }\end{array}$ & $\begin{array}{l}\text { Anthocyanin(mg/100g } \\
\text { f.w) }\end{array}$ & TSS \% & $\begin{array}{c}\text { Total } \\
\text { Acidity } \%\end{array}$ & $\begin{array}{c}\text { Vit. C } \\
\text { (mg/100g } \\
\text { f.w) }\end{array}$ & $\begin{array}{c}\text { Total } \\
\text { sugars\% }\end{array}$ & $\begin{array}{l}\text { Anthocyanin(mg/100g } \\
\text { f.w) }\end{array}$ \\
\hline $120 \%$ RDK & & 9.6 & 1.08 & 51.0 & 6.85 & 81.8 & 9.4 & 1.15 & 53.0 & 7.11 & 87.0 \\
\hline $100 \%$ RDK & & 9.7 & 1.24 & 54.0 & 6.96 & 85.1 & 10.1 & 1.18 & 55.2 & 7.27 & 91.0 \\
\hline $80 \%$ RDK+potassin & & 11.5 & 1.24 & 55.3 & 7.11 & 88.1 & 11.2 & 1.17 & 56.1 & 7.46 & 93.6 \\
\hline 60\% RDK+potassin & & 8.0 & 1.19 & 47.7 & 6.60 & 80.5 & 8.5 & 1.08 & 49.2 & 6.93 & 84.5 \\
\hline \multirow[t]{5}{*}{ LSD at 5\% } & & 0.04 & 0.15 & 1.4 & 0.04 & 1.4 & 0.07 & NS & 1.1 & 0.07 & 0.9 \\
\hline & Chelated B at 100ppm & 10.6 & 1.16 & 55.4 & 7.15 & 88.5 & 11.8 & 1.1 & 57.0 & 7.4 & 93.1 \\
\hline & $\begin{array}{l}\text { Boric acid at 100ppm } \\
\text { NanoBoron at }\end{array}$ & 10.2 & 1.08 & 53.3 & 7.01 & 84.6 & 10.0 & 1.1 & 54.7 & 7.3 & 90.1 \\
\hline & 100ppm & 9.4 & 1.22 & 51.1 & 6.82 & 82.6 & 9.3 & 1.2 & 52.3 & 7.1 & 88.2 \\
\hline & Control & 8.6 & 1.30 & 48.3 & 6.53 & 79.8 & 8.2 & 1.2 & 49.6 & 7.0 & 84.7 \\
\hline \multirow[t]{2}{*}{ LSD at 5\% } & & 0.08 & 0.16 & 1.2 & 0.08 & 1.4 & 0.08 & 0.10 & 1.4 & 0.08 & 1.6 \\
\hline & Chelated B at 100ppm & 10.0 & 1.00 & 54.6 & 7.10 & 86.2 & 10.8 & 1.10 & 56.3 & 7.28 & 91.1 \\
\hline \multirow[t]{4}{*}{$120 \%$ RDK } & $\begin{array}{l}\text { Boric acid at 100ppm } \\
\text { NanoBoron at }\end{array}$ & 9.9 & 1.00 & 51.4 & 6.99 & 82.8 & 9.2 & 1.10 & $\mathbf{5 3 . 7}$ & 7.14 & 88.4 \\
\hline & $100 p p m$ & 9.8 & 1.13 & 50.2 & 6.85 & 80.7 & 8.3 & 1.20 & 52.4 & 7.07 & 86.3 \\
\hline & Control & 8.9 & 1.17 & 48.0 & 6.44 & 77.5 & 9.4 & 1.20 & 49.6 & 6.93 & 82.1 \\
\hline & Chelated B at 100ppm & 10.9 & 1.27 & 57.4 & 7.19 & 89.7 & 12.5 & 1.10 & 58.1 & 7.43 & 94.3 \\
\hline \multirow[t]{5}{*}{$120 \%$ RDK } & $\begin{array}{l}\text { Boric acid at 100ppm } \\
\text { NanoBoron at }\end{array}$ & 10.1 & 1.10 & 55.6 & 7.08 & 85.4 & 10.1 & 1.10 & 57.3 & 7.30 & 91.7 \\
\hline & $100 \mathrm{ppm}$ & 9.8 & 1.33 & 52.8 & 6.96 & 83.9 & 9.8 & 1.30 & 53.9 & 7.22 & 90.5 \\
\hline & Control & 8.1 & 1.27 & 50.2 & 6.62 & 81.2 & 8.0 & 1.20 & 51.4 & 7.13 & 87.3 \\
\hline & Chelated B at 100ppm & 13.1 & 1.27 & 58.3 & 7.36 & 92.6 & 13.9 & 1.10 & 59.7 & 7.68 & 97.5 \\
\hline & $\begin{array}{l}\text { Boric acid at } 100 \mathrm{ppm} \\
\text { NanoBoron at }\end{array}$ & 12.2 & 1.00 & 56.5 & 7.14 & 88.5 & 11.4 & 1.10 & 56.9 & 7.52 & 94.2 \\
\hline \multirow[t]{4}{*}{ 80\% RDK+potassin } & $100 \mathrm{ppm}$ & 10.9 & 1.27 & 54.5 & 7.05 & 86.3 & 11.0 & 1.17 & 55.2 & 7.41 & 92.9 \\
\hline & Control & 9.6 & 1.43 & 51.9 & 6.89 & 85.1 & 8.5 & 1.30 & 52.6 & 7.24 & 89.8 \\
\hline & Chelated B at 100ppm & 8.6 & 1.10 & 51.2 & 6.96 & 85.6 & 9.8 & 1.00 & 53.8 & 7.12 & 89.3 \\
\hline & Boric acid at 100ppm & 8.6 & 1.20 & 49.6 & 6.84 & 81.7 & 9.4 & 1.10 & 50.8 & $\mathbf{7 . 0 4}$ & 85.9 \\
\hline \multirow[t]{3}{*}{$60 \%$ RDK+potassin } & NanoBoron at & & & & & & & & & & \\
\hline & $100 p p m$ & 7.0 & 1.13 & 46.8 & 6.43 & 79.4 & 8.0 & 1.10 & 47.6 & 6.89 & 83.2 \\
\hline & Control & 7.8 & 1.33 & 43.3 & 6.17 & $\mathbf{7 5 . 3}$ & 7.0 & 1.13 & 44.6 & 6.68 & 79.5 \\
\hline LSD at 5\% & & 0.15 & 0.30 & 2.4 & 0.15 & 2.9 & 0.16 & 0.19 & 2.5 & 0.16 & 2.8 \\
\hline
\end{tabular}


4. Chemical fruit quality.

Date recorded in Table 4 indicate that fertilizing the plants with mineral fertilizer $(\mathrm{K})$ at the recommended dose or either increasing the rate of application to $120 \%$ without bio fertilizer or decreasing it to $80 \%$ of the recommended dose with bio fertilizer significantly affected all chemical fruit quality such as TSS, vitamin $\mathrm{C}$, total acidity and anthocyanine content during both seasons except the total acidity during the second season which didn't reach the level of significance. In this respected, $80 \%$ of recommended dose with added bio fertilizer $(280 \mathrm{~kg} / \mathrm{Fed}$. potassium sulphate+ potassin) and $120 \%$ of recommended dose (420 kg/Fed.potassium sulphate) treatments recorded the highest values in all assayed chemical constituents during both seasons of study. On the other hand the lowest values in all assayed chemical constituents were recorded with fertilizing strawberry plants with $60 \%$ of the recommended dose potassium during the two seasons of growth. This results are in agreement with those reported by Lisjak et al. (2008), Treder et al. (2014), Afroz et al. (2016), Kumari et al.(2018), Schwarz et al. (2018) and Morais et al.(2019) .

Such date present in Table 4 show that total soluble solids (T.S.S), vitamin C, total acidity and total sugars as well as anthocyanine content of fruit were significantly affected due to spraying the plants with either Chelated boron or Boric acid at 100ppm compared with the control treatments. In this connection, the highest value in all determined chemical constituents were recorded in case of spraying the plants with Chelated boron followed by using Boric acid except the total acidity which was higher in case of the control treatment. Obtained results were true during both season of study. Bragg et al. (2008), Esringu et al. (2011), Rafeii and Pakkish (2014), Ozkutlu et al. (2017) and Rosa et al. (2018) reported similar results .

As for the effect of the interaction, data in Table 4 show that the highest values in all studied chemical fruit quality traits except total titratable acidity, were recorded as result of application $80 \%$ of the potassium recommended dose with bio fertilizer $(280 \mathrm{~kg} / \mathrm{Fed}$ potassium sulphate+ potassin) and foliar spray the plants with Chelated boron at 100ppm compared with the other interaction treatments. Meanwhile, the highest values of fruit total acidity content were recorded as a result of application $80 \%$ of the potassium recommended dose $(280 \mathrm{~kg} / \mathrm{Fed}$. potassium sulphate) and foliar spray the plants with tab water (control treatment). Obtained results are true during both seasons of study.

\section{References}

A. O.A. C. 1990. Official and tentative methods of analysis. Association of Official Analytical Chemists. Washington, D.C,U.S.A.

Afroz, C. A.; M. A. H. Shimul; M. Ikrum; M. A. Siddiky; M. A. Razzaque. 2016. Effects of nitrogen phosphorus potassium and sulphur on growth yield and nutrient content of strawberry (Fragaria ananassa). J. of Environmental Sci. and Natural Resources, 9(1):99-108.

Bragg, N. C.; B. J. Chambers; J. S. Davies and I. R. Richards. 2008. The effects of increasing levels of boron on the growth and yield of strawberries grown in peat-based systems.

Brown, J. and O. Lilliland. 1946. Rapid determination of potassium and sodium in plant material and soil extracts by flame photometric. Proc. Amer. Soc. Hort. Sci, 48: 341- 346.

Esringu, A.; M. Turan; A. Gunes; A. Esitken and P. Sambo. 2011. Boron application improves on yield and chemical composition of strawberry. Acta Agric. Scandinavica. Section B, Plant Soil Sci., 61(3):245-252.

John, M. K. 1970. Colorimetric determination of phosphorus in soil and plant material with ascorbic acid. Soil Sci., 109:214-220.

Karlidag, H.; E. Yildirim; M. Turan and M. F. Donmez. 2010. Effect of plant growth-promoting bacteria on mineral-organic fertilizer use efficiency, plant growth and mineral contents of strawberry (Fragaria x ananassa L. Duch.). Ecofruit. 14th International Conference on Organic Fruit-Growing. Proceedings for the conference, Hohenheim, Germany, 22-24 February 2010; 2010. : 218-226.

Kumari, S.; M. Kuldeep and S. Niranjan. 2018. Studies on the effect of plant growth promoting rhizobacteria (PGPR) on growth, physiological parameters, yield and fruit quality of strawberry cv. Chandler. J. of Pharmacognosy and Phytochemistry, 7(2): 383-387

Lisjak, M.; A. Stanisavljevic; M. Spoljarevic and B. urevic. 2008. Potassium rate and accompanying anions impact on potassium, calcium and magnesium uptake by strawberries in soilless culture. Cereal Res. Communications, 36(Suppl. 5):483-486.

Morais, M. C.; A. Mucha; H. Ferreira; B. Goncalves; E. Bacelar and G. Marques. 2019. Comparative study of plant growth-promoting bacteria on the physiology, growth and fruit quality of strawberry. J. of the Sci. of Food and Agric., 99(12):5341-5349.

Nelson, N. 1974. A photometric adaptation of the somogyi methods for determination of glucose. J. Biology. Chem. 195: 19-23.

Ozkutlu, F.; O. Ete; M. Akgun; F. Akdin; Y. Tutus and B. Ozcan. 2017. Boron fertilization effects on strawberry plant for preventing decomposed shaped fruit generation and on mineral content of leaves. Akademik Ziraat Dergisi, 6(2):153-160.

Pregl, E. 1945. Quantitative organic micro analysis. $4^{\text {th }}$ Ed. J. Chundril, London.

Rafeii, S. and Z. Pakkish. 2014. Improvement of Vegetative and Reproductive Growth of 'Camarosa' Strawberry: Role of Humic Acid, Zn, 
and B. Agric. Conspectus Scientifi cus ., 79 (4): 239-244.

Rosa, D. dalla; F. Villa; D. R. Stumm; J. Lucini; F. Corbari; T. F. Bueno and J. Egewarth. 2018. Boron fertilization on strawberry cv. Camarosa. Revista Agrarian, 11(41):211-218.

Rowell, D. L. 1995. Soil Science methods and application data. Library of Congress cataloging publication data. New York, NY1058.USA.

Schwarz, K.; J. T. Vilela-Resende; C. Pierozan Junior; J. Tauffer-de Paula; J. E Baier; M. L. de Souza-Silva and F. Brendler-Oliveira. 2018. Yield and nutrition of greenhouse-grown strawberries (Fragaria x ananassa (Duchesne ex Weston) Duchesne ex Rozier. cv. Camarosa) as affected by potassium fertilization. Acta
Agronomica, Universidad Nacional de Colombia, 67(1):114-119.

Snedecor, G. W. and W.G. Cocharn. 1991. Statistical methods. $8^{\text {th }}$ E.d., lowa State Univ. press, Lowa. USA

Treder, W.; A. Tryngiel-Gac and K. Klamkowski. 2014. Studies on the effect of growing medium and monopotassium phosphate on rooting and quality of strawberry potted plantlets. Acta Scientiarum Polonorum - Hortorum Cultus, 13(5):49-60.

Tripathi, V. K.; J. Ankita; K. Sanjeev; D. Vishal and K. Abhinav. 2017. Efficacy of bio-fertilizers and mulching on growth, yield and quality of strawberry (Fragaria x ananassa) cv. Chandler. Indian J. of Agric. Sci., 87(9):1179-1183.

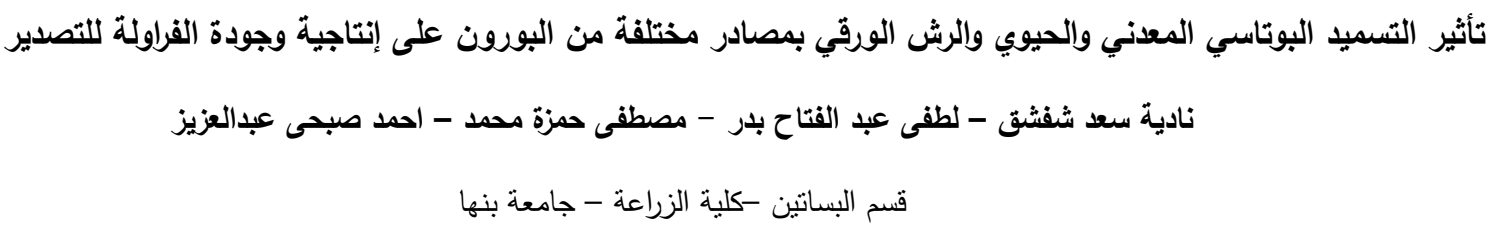

